\title{
ANALISIS EKSTRAK TUMBUHAN REMPAH SEBAGAI PRESERVATIVES MAKANAN TAHU DIUJI SECARA IN VITRO
}

\author{
N.L.P.M Widiyanti ${ }^{1}$, S.Mulyadiharja ${ }^{2}$, I.N. Sukarta ${ }^{3}$ \\ 12 Jurusan Pendidikan Biologi, Universitas Pendidikan Ganesha \\ Singaraja, Indonesia \\ 2 Jurusan Analis Kimia, Universitas Pendidikan Ganesha \\ Singaraja, Indonesia \\ e-mail : manikwidiyanti@gmail.com, sanusimulyadiharja@yahoo.com, \\ Sukartainyoman@gmail.com
}

\begin{abstract}
Abstrak
Tanaman rempah sebagai antibakteri pada makanan tahu dan sebagai alternatif pengawet makanan pengganti pengawet kimia berbahaya seperti formalin dan methyl yellow antara lain Cymbopogon ciratus, Cucurma domestika dan Alpinia galanga. Tahu yang berhasil dibuat masih belum memenuhi standar penilaian SNI 01-3142-1992 yaitu bagian rasa, $50 \%$ panelis menyatakan rasa tahu sedikit asam. Uji organoleptik menunjukkan terjadi penurunan kualitas tahu pada hari ke-tiga dan ke-enam baik pada aroma, rasa, warna dan penampakan tahu. Analisis dengan gain score menunjukkan penurunan kualitas ke tiga preservatives dalam menghambat pertumbuhan bakteri masa perendaman tahu. Analisis univariat menunjukkan terdapat perbedaan bermakna ketiga preservatives dengan konsentrasi berbeda terhadap jumlah $S P C$ bakteri dengan $p<0,05$. Analisis univariat menunjukkan terdapat perbedaan bermakna ketiga preservatives dengan konsentrasi berbeda terhadap zona hambatan pertumbuhan bakteri dengan $\mathrm{p}<0,05$. Uji koefisien phenol menunjukkan ke- 3 preservatives alami yang diekstrak dengan hidrodestilasi dengan nilai sama atau kurang efektif dibandingkan phenol.
\end{abstract}

Kata kunci : tanaman rempah, pengawet alami, makanan tahu, uji in vitro

\begin{abstract}
Spice plants as an antibacterial in tofu and is as a natural food preservative alternative replacement harmful chemical preservatives such as formalin and methyl yellow include Cymbopogan ciratus, Cucurma domestica and Alpinia galanga. Tofu that has been created is still not meet the assessment standards of SNI 01-3142-1992 in aroma part, whereas $50 \%$ panelists who stated aroma tofu is slightly acidic. Organoleptic test showed a decline in quality on third and the sixth days both in aroma, taste, color and performance of tofu. Gain score analysis showed a decrease in the quality of the three kinds preservatives in inhibit growth of bacteria during tofu soaked. Univariat analysis showed there were significant differences of three kinds preservatives with different concentrations toward number SPC of bacteria with $p<0.05$. Univariat analysis showed there were significant differences of three kinds preservatives with different concentrations toward the bacteria growth inhibition zone with $p<0.05$. Coeffisient phenol test showed three kinds of natural preservatives was extracted by hydrodestillation with value equal or less effective than pure phenol.
\end{abstract}

Keywords : spice plants, natural preservatives, tofu, in vitro test.

\section{PENDAHULUAN}

Tahu merupakan makanan tradisional bagi masyarakat Indonesia. Penelitian
Karyasa (1993), diperoleh data bahwa $10 \%$ penduduk Indonesia mengkonsumsi tahu sebanyak 100 gram per hari. Berarti sekitar 
2 juta kilogram tahu dibutuhkan setiap harinya. Komposisi tahu yang banyak mengandung protein dan air menyebabkan tahu merupakan media yang cocok untuk tumbuhnya mikroba sehingga tahu menjadi cepat mengalami kerusakan (Sarwono dan Saragih, 2003). Karyasa (2000) menyatakan bahwa tahu sebagai bahan makanan yang murah dan praktis memiliki keunggulan sebagai bahan makanan yang bagus untuk peningkatan kesehatan intelektual (geist), akal (verstand), semangat dan sikap (gessinung). Tahu juga mempunyai khasiat sebagai anti stress menurunkan nervositas dan mengurangi depresi. Penelitian yang dilakukan oleh Midayanto \& Yuwono (2014) mendapatkan bahwa nilai tekstur tahu yang disukai oleh panelis dan direkomendasikan kepada SNI adalah kisaran 5-7 N/m ${ }^{2}$

Kadar protein yang tinggi dan kadar air tinggi, tahu mudah mengalami pembusukan oleh bakteri. Hasil penemuan BPOM pada makanan yang di indikasikan menggunakan formalin dan boraks antara lain pada : tahu. Tahu biasanya dicampur dengan formalin, memiliki ciri tidak mudah rusak sampai tiga hari dan mampu bertahan sampai 15 hari pada suhu lemari es, dari segi fisik tahu terlampau keras, kenyal namun tidak padat. Akhir tahun 2005 dan awal tahun 2006 publikasi tentang penyalahgunaan formalin pada bahan makanan termasuk tahu sangat gencar pada media massa di Indonesia. Hasil sampling dan laboratorium di beberapa kota besar di Indonesia diketahui bahwa sebesar 1,91\% tahu mengandung formalin dengan prosentase terbesar pada Kotamadya Kediri yaitu 10,42 \% (Sampurno, 2006). Penelitian yang dilakukan oleh Pratiwi dkk (2015) menunjukkan bahwa ditemukan bahwa salah satu sampel tahu yang berasal dari pasar tradisional di Bandung mengandung pewarna kuning sintetik metanil. Afrianto (2008) menyatakan bahwa makanan yang rawan dicampur bahan berbahaya ini biasanya seperti bahan makanan basah seperti ikan, mie, tahu hingga jajanan anak di sekolah.

Menurut Peraturan MenKes Nomor 1168/MenKes/PER/X/1999, formalin merupakan bahan kimia yang penggunaannya dilarang untuk produk makanan (Nuryasin, 2006). Formalin merupakan bahan kimia yang bersifat karsinogenik (penyebab kanker) dan mutagen (menyebabkan perubahan sel fungsi hati dan jaringan) (BPOM 1993). Menurut Rahmawati (FT UNY, tanpa tahun) formalin bersifat desinfektan kuat terhadap bakteri pembusuk dan jamur. Oleh karena itu gas formalin dipakai oleh pedagang bahan tekstil supaya tidak rusak oleh jamur atau ngengat. Selain itu formalin juga dapat mengeraskan jaringan sehingga dipakai sebagai pengawet mayat dan digunakan pada proses pemeriksaan bahan biologi maupun patologi.

Jivai \& Yetti (2008) melakukan uji pengaruh pemberian makanan tahu berformalin terhadap gangguan fungsi hati dan terbentuknya radikal bebas dalam tubuh tikus dengan menetapkan kadar SGOT (Serum Glutamate Oxaloacetate Transferase), SGPT (Serum Glutamate Piruvate Transferase) dan kadar MDA (malondialdehid) setelah memberikan tahu berformalin secara oral selama 25 hari kepada dua kelompok tikus dengan kadar yang berbeda $(0,25 \%$ dan $0,50 \%)$ dengan hasil penelitian menunjukkan bahwa terjadi cenderung peningkatan kadar SGOT, SGPT dan MDA dalam darah tikus yang diberikan tahu berformalin dibandingkan dengan kelompok kontrol.

Berdasarkan pemasalahan tersebut, solusi alternatif yaitu memanfaatkan bahan pengawet alami. Bahan pengawet alami merupakan jenis pengawet yang memiliki banyak khasiat, terutama sebagai bahan pengawet makanan. Bahan pengawet alami relatif aman dibandingkan bahan pengawet sintetis yang jika terjadi ketidaksempurnaan proses dapat mengandung zat-zat yang berbahaya bagi kesehatan dan kadangkadang bersifat karsinogenik (Winarno \& Rahayu 1994). Rempah-rempah merupakan pengawet alami yang mengandung zat antimikroba yang khas sehingga dapat digunakan untuk mengawetkan suatu bahan makanan antara lain minyak atsiri tanaman sereh (Cymbopogon ciratus), ekstrak kunyit (Cucurma domestika) dan lengkuas (Alpinia galanga) untuk menghambat pertumbuhan bakteri, sehingga dapat digunakan sebagai bahan pengawet alami pada makanan tahu.

Penelitian yang dilakukan oleh Norma dkk (2014) mendapatkan bahwa terjadi kerusakan hepatoksisitas hati pada hewan 
model kelinci akibat pemberian ekstrak etanol herba kompri (Symphytum officinale L). Belum ada penelitian pengaruh preservative alami sereh (Cymbopogon ciratus), ekstrak kunyit (Cucurma domestika) dan lengkuas (Alpinia galanga) terhadap kadar SGOT (Serum Glutamat Oxaloacetate Transferase), SGPT (Serum Glutamat Pirivate Transferase) dan struktur jaringan hepatik tikus Wibstar.

\section{METODE PENELITIAN}

Rancangan penelitian adalah rancangan acak lengkap dengan rancangan true experimental : The Randomized Pre Test-Post Test Control Group Design. Sebagai variabel bebas penelitian adalah makanan tahu yang diawetkan dengan variasi konsentrasi preservative alami. Variabel terikat penelitian adalah (1) uji organoleptik makanan tahu yang berhasil dibuat diuji dengan berdasar SNI 01- 31421992 (Mustafa, 2006) (2) Uji organoleptik makanan tahu yang diawetkan dengan preservatives alami (Cymbopogon ciratus), ekstrak kunyit (Cucurma domestika) dan lengkuas (Alpinia galanga) (3) Jumlah total (SPC) bakteri yang diisolasi dari makanan tahu yang dibuat (4) Jumlah SPC bakteri yang dipreservasi dengan preservatives alami (5) Ukuran zona hambat preservative alami sereh (Cymbopogon ciratus), ekstrak kunyit (Cucurma domestika) dan lengkuas (Alpinia galanga) dengan konsentrasi berbeda terhadap bakteri Staphylococcus aureus dan polikultur bakteri yang diisolasi dari makanan tahu (6) Uji koefisien phenol dari germisida preservatives alami sereh (Cymbopogon ciratus), ekstrak kunyit (Cucurma domestika) dan lengkuas (Alpinia galanga) terhadap hambatan pertumbuhan mikroba yang diisolasi dari makanan tahu (7) Lama simpan makanan tahu yang dibuat dan direndam dalam air dibandingkan dengan menggunakan preservatives alami sereh (Cymbopogon ciratus), ekstrak kunyit (Cucurma domestika) dan lengkuas (Alpinia galanga) dengan konsentrasi berbeda. Analisa data penelitian tentang (1) Uji organoleptik makanan tahu yang berhasil dibuat dan makanan tahu dipreservasi dengan preservatives alami dianalisis secara deskriptif (2) Uji pemeriksaan awal dan selama perlakuan, dilakukan dengan pre test-post test control group design dengan gain score (3) Jumlah total (SPC) mikroba yang diisolasi dari makanan tahu dalam preservatives alami dianalisis dengan uji univariat (4) Lama simpan tahu dianalisis dengan secara deskriptif (5) Hasil ukur zona hambatan preservatives alami terhadap mikroba yang diisolasi dari makanan tahu dianalisis dengan uji univariat (6) Uji koefisien phenol dari germisida uji dianalisis dengan uji koefisien phenol dari bahan kimia uji

\section{Alat dan Bahan \\ Alat}

Hydrodestilasi (modifikasi), statif, penangas elektrik, erlenmeyer, blender, beker glass senduk pengaduk, kain kasa, pencetak tahu, pemberat untuk cetakan tahu, pisau dapur, cawan plastik, aluminium foil, kapas, cawan petri, tabung reaksi dan raknya, pipet, gelas ukur, pinset, spoit, ose, gunting, kertas label, timbangan elektrik, autoclave, inkubator, laminar airflow, nampan, spidol, tolly counter, cotton bud, colony counter, kertas wattman, masker, sarung tangan dan beberapa penutup kepala, pencatat data.

\section{Bahan}

Kedele, asam asetate, aquades steril, sereh, kunyit, lengkuas, Nutrient Agar (NA), laktosa, pepton, phenol, bakteri isolat murni Staphylococcus aureus, bakteri polikultur isolasi dari makanan tahu.

\section{Prosedur Penelitian}

A. Pembuatan preservatives alami dari sereh (Cymbopogon ciratus), kunyit (Cucurma domestika), dan lengkuas (Alpinia galanga)

Caranya adalah sebagai berikut (Ranitha et al, 2014) : Preservatives alami dari sereh (Cymbopogon ciratus) : (a) Daun sereh dibeli dari petani di areal pertanian Bangah Panji Buleleng Bali dilayukan selama 1 minggu dengan cara dibungkus menggunakan plastik (b) Ditimbang sebanyak 200 gram daun sereh (c) Daun sereh dipotong-potong dengan panjang kirakira $10 \mathrm{~cm}$ dengan menggunakan gunting (d) Ditambahkan aquades steril sebanyak 1600 $\mathrm{ml}$ pada potongan sereh (e) Dihancurkan dengan blender (Miyako, volume 2 liter) selama 10 menit (f) Disaring untuk memisahkan ampas dan larutan (g) 
Dilakukan hidrodistilasi untuk mendapatkan ekstrak sereh

Preservatives alami dari kunyit (Cucurma domestika) dan lengkuas (Alpinia galanga) menurut prosedur Ranitha et al, 2014 sebagai berikut. (a) Rimpang kunyit dan lengkuas dibeli di pasaran dengan berat dan ukuran yang sama (10-20 gram) (b) Dibuat simplisia kunyit dan lengkuas dengan cara memotong kunyit dan lengkuas kirakira selebar $0,5 \mathrm{~cm}$. (c) Potongan kunyit dan lengkuas dijemur/dioven sampai kering dengan cara meremas potongan rempah sampai hancur (kadar air terendah). (d) Potongan kunyit dan lengkuas digiling dengan mesin penggiling tepung. (e) Ditimbang 150 gram tepung kunyit dan dicampur dengan $1800 \mathrm{ml}$ aquades steril serta ditimbang 100 gram tepung lengkuas dan dicampur dengan $1600 \mathrm{ml}$ air. (f) Dilakukan hidrodistilasi untuk mendapatkan ekstrak kunyit dan lengkuas

\section{B. Pembuatan makanan tahu}

Adapun cara pembuatan tahu adalah sebagai berikut. (a) Ditimbang dan disortir kedelai sebanyak 250 gram yang ukurannya mendekati sama. (b) Kedelai direndam selama 8-12 jam (c) Kedelai disaring dari air rendaman (ditiriskan) (d) Kedelai dihancurkan dengan menggunakan blender (merk Miyako Volume 2 literl) dan dengan $600 \mathrm{ml}$ air mendidih untuk membuat bubur kedelai (e) Ditambahkan sebanyak $900 \mathrm{ml}$ aquades steril pada bubur kedelai (f) Bubur kedelai dipanaskan sampai mendidih (g) Dilakukan penyaringan bubur kedelai untuk memisahkan ampas dan sari kedelai (h) Sari kedelai didapatkan sebanyak $1200 \mathrm{ml}$ (i) Dilakukan pendinginan sari kedelai sampai suhu $70^{\circ} \mathrm{C}$ (j) Ditambahkan larutan cuka 5\% sebanyak $75 \mathrm{ml}$ untuk pengendapan protein kedelai (dari uji pendahuluan). (k) Dilakukan pencetakan protein kedelali untuk menjadi tahu selama semalam (I) Tahu dipotong dengan menggunakan pisau dapur (m) Diuji oleh panelis berdasarkan kriteria $\mathrm{SNI} 01$ 3142-1992 (Mustofa, 2006) (n) Perendaman tahu yang dibuat dengan aquades steril dan preservatives alami dengan cara memotong tahu sebanyak 1,25 gram (Cappuccino \& Sherman, 1987) dan direndam dalam $7 \mathrm{ml}$ aquades steril dan preservatives alami untuk setiap konsentrasi
C. Total $(S P C)$ mikroba yang diisolasi dari makanan tahu yang telah dibuat dan tahu yang direndam dengan preservatives alami dilakukan sesuai dengan prosedur dari Cappuccino \& Sherman (1987), dengan cara sebagai berikut. (a) Tahu ditimbang seberat 1,25 gram dengan menggunakan timbangan elektrik (b) Ditambahkan aquades steril sebanyak 11,25 ml (c) Tahu dihancurkan dengan lumpang (c) Dilakukan pengenceran $10^{-1}$ sampai $10^{-6}$ dari larutan induk (d) Sebanyak $1 \mathrm{ml}$ masing-masing pengenceran dipindahkan pada cawan petri dan ditambahkan 15-20 ml Nutrient Agar (NA) dan dilakukan pencampuran (pour plate) dengan membentuk angka 8. (e) Dibuat juga kontrol (f) Diobservasi jumlah SPC bakteri yang tumbuh pada 0 hari, direndam selama 1 hari, 3 hari dan 6 hari

D. Dilakukan pengukuran zona hambatan preservatives alami terhadap mikroba yang diisolasi dari makanan tahu dan uji kontrol dengan bakteri Stapphylococcus aureus

Dilakukan dengan metode Kirby Bauer dari Cappuccino \& Sherman (1987), sebagai berikut. (a) Kertas Wattman dengan diameter $1 \mathrm{~cm}$ direndam ke dalam larutan ekstrak sereh, kunyit dan lengkuas konsentrasi $0 \%$ (kontrol), 20\%, 40\% dan $60 \%$ selama 20 menit untuk mendapatkan kertas yang jenuh esktrak (b) Dilakukan goresan/streak bakteri yang diisolasi dari tahu dan bakteri Stapphylococcus aureus pada permukaan media agar NA (mestinya digunakan Agar Mueller-Hinton) (c) Diamkan kultur selama 5 menit untuk dikeringkan (d) Dengan menggunakan pinset steril, diambil kertas Wattman dan diletakkan dengan cara menekan kertas Wattman pada permukaan goresan bakteri supaya kertas tahan menempel pada permukaan agar (f) Diinkubasi selama 24-48 jam pada suhu $37^{\circ} \mathrm{C}$ dengan posisi terbalik (g) Diukur zona hambatan

\section{E. Koefisien phenol dari bahan kimia uji \\ Dilakukan sesuai dengan prosedur} dari Cappuccino \& Sherman (1987), dengan cara sebagai berikut. (a) Phenol dilarutkan pada larutan Lactosa Broth $(L B)$ dengan perbandingan $1: 80 ; 1: 90$ dan 1 : 100. Ekstrak sereh, kunyit dan lengkuas 
dilarutkan pada larutan $(L B)$ dengan perbandingan 1: 400; 1:450 dan 1: 500. Ditambahkan bakteri uji (Staphylococcus aureus) sebanyak 1 tetes ke dalam larutan dan dipaparkan bakteri uji selama 5 menit, 10 menit dan 15 menit dengan cara mengaduk bakteri pada larutan untuk ketahanan kontak mikroba dengan desinfektan (b) Dengan tekhnik yang steril, pindahkan satu loop larutan dengan interval 5, 10 dan 15 menit ke dalam larutan $L B$ dan sebanyak $1 \mathrm{ml}$ ke dalam $N A$ (c) Diinkubasi semua kultur $L B$ selama 48 jam pada suhu $37^{\circ} \mathrm{C}$ dan $N A$ selama 24 jam dan 48 jam (d) Diamati ada atau tidak tumbuhnya mikroba. (e) Koefisien phenol dari bahan kimia uji dihitung dengan persamaan 1.

Koefisien fenol dari bahan uji $=$

larutan uji germisida yang menunjukkan tidak tumbuh pada paparan 10 menit tetapi pada paparan 5 menit larutan uji fenol yang menunjukkan tidak tumbuh pada paparan 10 menit, tetapi pada paparan 5 menit ....Pers. 1

F. Lama simpan tahu

Dilakukan dengan menghitung total $(S P C)$ mikroba yang diawetkan dibandingkan dengan kontrol sesuai prosedur dari Cappuccino \& Sherman (1987) dan dari uji organoleptik makanan tahu. Penjelasan pada C

\section{HASIL DAN PEMBAHASAN}

\section{A. Hasil Penelitian \\ 1. Karakteristik tahu yang berhasil dibuat}

Hasil dari tahu yang berhasil dibuat sesuai dengan uji pendahuluan didapatkan karakteristik tahu dengan tekstur yang padat dengan bau yang normal tahu, rasa normal tahu, warna putih bersih dengan penampakan tidak berlendir dan tidak berjamur. Dari uji organoleptik oleh panelis, didapatkan seperti tertera pada tabel 01 . Seratus persen (100\%) panelis menyatakan bahwa tahu yang dibuat dengan bau normal tahu, 50\% panelis menyatakan rasa normal tahu dan $50 \%$ panelis menyatakan tahu yang berhasil dibuat sedikit asam. Sedangkan dari warna : $100 \%$ panelis menyatakan tahu yang dibuat dengan warna putih bersih atau kekuningan bersih. Tahu yang berhasil dibuat menunjukkan penampakkan seperti yang dinyatakan oleh panelis adalah : 100\% normal tahu yaitu tidak berlendir dan berjamur. Uji organoleptik makanan tahu pada hari pertama perendaman dengan preservatives alami. Sebanyak $100 \%$ panelis menyatakan tahu yang direndam dengan preservative alami sereh pada hari I dengan bau/aroma dan rasa harum sereh. Karakteristik warna tahu, $100 \%$ panelis menyatakan putih bersih atau kekuningan bersih dan $100 \%$ panelis menyatakan penampakkan normal tidak berlendir dan berjamur. Pada hari ke-3 $100 \%$ panelis menyatakan bahwa tahu yang direndam dengan preservatives alami sereh bearoma asam, sebanyak $80 \%$ panelis menyatakan tahu yang direndam dengan preservatives alami kunir bearoma asam dan $20 \%$ lainnya menyatakan beraroma kecut. Sedangkan tahu yang direndam dengan preservatives alami lengkuas, sebanyak $60 \%$ panelis menyatakan beraroma asam, dan masing-masing 20\% panelis lainnya menyatakan beraroma harum lengkuas dan kecut. Terhadap rasa dan warna, pada perendaman tahu hari ke3 terhadap semua preservatives, masingmasing $100 \%$ panelis menyatakan bahwa tahu berasa kecut dan berwarna krem. Tahu yang direndam dengan ke-3 preservatives alami, dinyatakan oleh panelis dengan $80 \%$ menyatakan norma tidak berlendir dan berjamur dan 20\% menyatakan tidak berlendir tetapi berjamur. Perendaman tahu pada hari ke-6, terjadi penurunan jumlah panelis, karena sebagian besar panelis tidak berani merasakan tahu yang direndam pada hari ke-6, karena perubahannya sangat menyolok (hasil wawancara pribadi, Juni 2016). Sebanyak $100 \%$ panelis menyatakan $100 \%$ panelis menyatakan tahu beraroma asam, berasa kecut, berwarna coklat muda dan penampakan berlendir dan berjamur. Sedangkan dengan preservatives kunir, sebanyak masing-masing $50 \%$ panelis menyatakan aroma tahu beraroma asam dan kecut, masing-masing 100\% menyatakan berasa kecut dan berwarna coklat muda, dan $100 \%$ panelis menyatakan penampakan tahu berlendir dan berjamur. Tahu yang direndam dengan preservative 
lengkuas masing-masing sebanyak $60 \%$ panelis menyatakan tahu beraroma asam, berasa kecut, berwarna coklat muda dan masing-masing 40\% lainnya menyatakan tahu beraroma kecut, berasa pahit, berwarna coklat tua. Sedanyak 100\% panelis menyatakan bahwa tahu yang direndam dengan preservative lengkuas pada hari ke-6 dengan penampakan berlendir dan berjamur.

Analisis data dari uji organoleptik awal (sebelum dipreservatives dengan preservatives alami), didapatkan bahwa tahu yang berhasil dibuat masih belum memenuhi standar penilaian SNI 01-31421992 yaitu pada bagian rasa, sebanyak 50\% panelis yang menyatakan memenuhi SNI 01-3142-1992 dan 50\% panelis yang menyatakan rasa sedikit asam. Asat asetat digunakan untuk menggumpalkan protein kedelai, mempunyai rasa asam. Kemungkinan rasa asam ini yang menyebabkan rasa tahu menjadi asam oleh sebagian panelis. Menurut Anonim (2003), asam asetat yang digunakan untuk menggumpalkan sari kedele sebanyak 16\% dari berat kering kedele.

Uji organoleptik makanan tahu pada hari pertama perendaman dengan preservatives alami. Sebanyak 100\% panelis menyatakan tahu yang direndam dengan ke-3 preservative alami pada hari I dengan bau/aroma dan rasa harum preservatives alami (sereh, kunyit dan lengkuas). Karakteristik warna tahu, 100\% panelis menyatakan putih bersih atau kekuningan bersih dan $100 \%$ panelis menyatakan penampakkan normal tidak berlendir dan berjamur. Terjadi penurunan kualitas tahu dari uji organoleptik pada hari ke-tiga dan ke-enam baik pada aroma, rasa, warna dan penampakan tahu. Penelitian ini mendapatkan tahu yang lebih awet sehari dibandingkan penelitian yang dilakukan oleh Mustofa (2006) yang mendapatkan bahwa pada hari ke dua, semua tahu yang mengalami perlakuan mulai mengalami tanda-tanda kerusakan, seperti adanya lendir, aroma sedikit asam, kekompakan berkurang, dan larutan perendam yang sangat keruh serta terdapat residu (semacam lendir) pada larutan perendamnya. $\mathrm{Hal}$ ini kemungkinan disebabkan taraf konsentrasi yang digunakan belum cukup efektif untuk menghambat pertumbuhan mikroba pada tahu yang berbeda dengan bahan makanan lainnya. Konsentrasi yang digunakan untuk kedua bentuk bahan pengawet alami tersebut adalah kunyit $0.2,0.4,0.6,0.8,1 \%$ $(\mathrm{w} / \mathrm{v})$ (Mustofa, 2006). Dibandingkan dengan tahu yang diawetkan dengan bahan kimia berbahaya yaitu formalin dengan daya awet tahu yang lebih lama. Ini sesuai dengan yang dinyatakan oleh Mudjajanto (2005) menyatakan bahwa tahu yang berformalin memiliki ciri-ciri, (1) Semakin tinggi kadar formalin maka tercium bau obat yang semakin menyengat, sedangkan tahu yang tidak berformalin akan tercium bau yang khas protein kedelai. (2) Tahu yang berformalin mempunyai sifat membal jika ditekan terasa sangat kenyal, sedangkan tahu tidak berformalin, jika ditekan akan hancur. (3) Tahu berformalin akan tahan lama, sedangkan tahu yang tidak berformalin hanya dapat tahan 1 atau 2 hari. (4) Jika tahu yang memaki pewarna buatan dapat ditambahi dengan cara melihat penampakannya, yaitu warnanya homogen dan penampakan mengkilat, sedangkan jika memakai pewarna kunyit warnanya cenderung tidak menarik dan buram, bagian dalamnya warnanya tidak homogen, bahkan ada sebagian yang berwarna putih. 


\section{Jumlah Standard Plate Count (SPC) bakteri}

\subsection{Jumlah rata-rata SPC bakteri sebelum dan setelah perlakuan}

Gain score jumlah rata-rata SPC bakteri sebelum dan sesudah perlakuan.

Gain Score = Jumlah bakteri awal-jumlah bakteri akhir

Tabel 1. Hasil Gain Score SPC bakteri

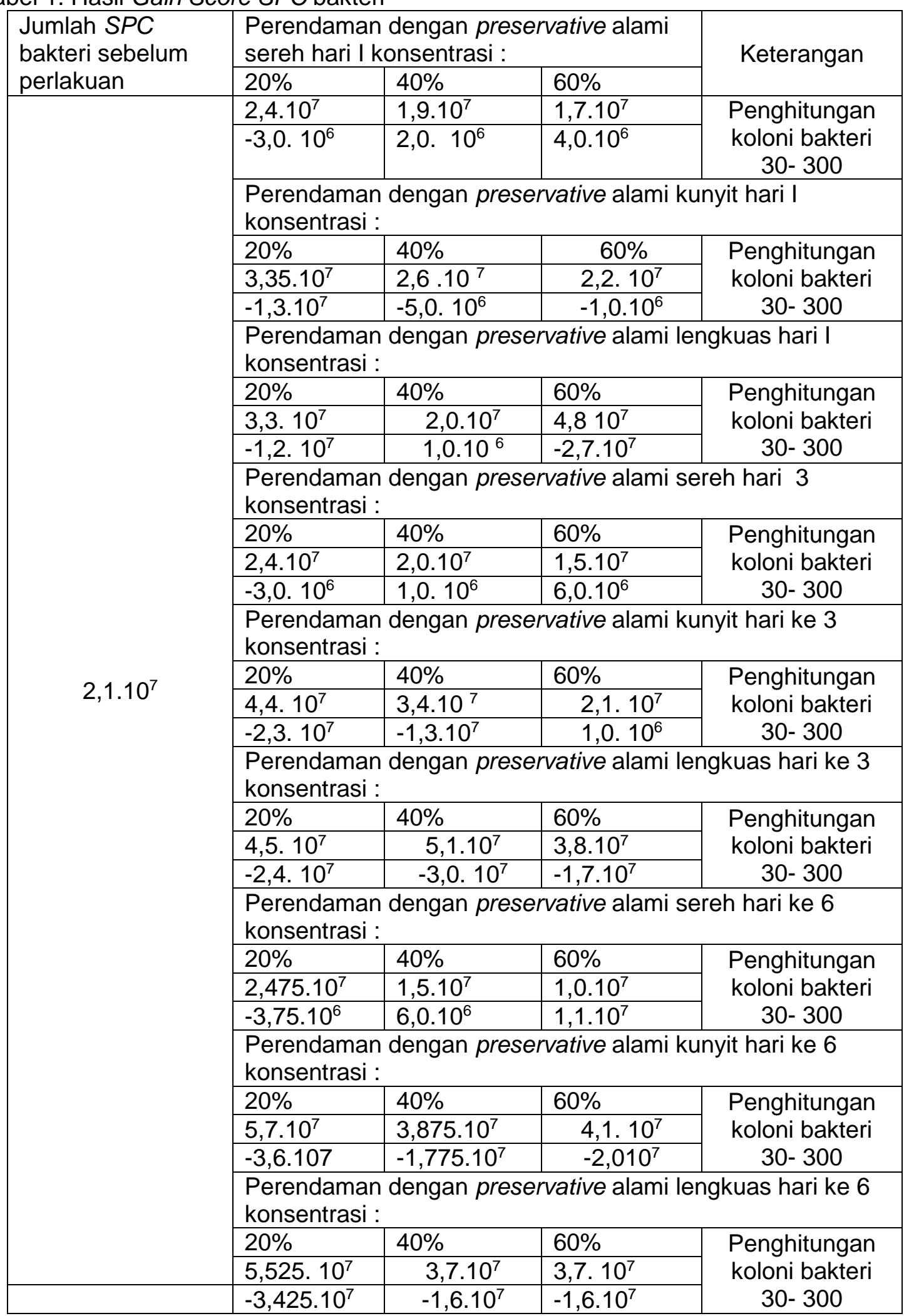


1. Uji autokorelasi antara variable bebas yaitu jenis preservatives dan waktu pemaparan, dengan hasil (jumlah SPC bakteri) tidak terdapat autokorelasi diantara variabel bebas, dengan nilai Durbin-Watson adalah 1 seperti tabel 3 di bawah ini.

Tabel 2. Hasil uji autokorelasi preservatives dengan waktu pemaparan Model Summary ${ }^{\mathrm{b}}$

\begin{tabular}{llrrrrr}
\hline Model & $\mathrm{R}$ & $\mathrm{R}$ Square & $\begin{array}{c}\text { Adjusted } \mathrm{R} \\
\text { Square }\end{array}$ & $\begin{array}{c}\text { Std. Error of } \\
\text { the Estimate }\end{array}$ & Durbin-Watson & \\
\hline 1 & $.458^{\mathrm{a}}$ & .210 & .195 & $1.48758 \mathrm{E} 7$ & & 1.333
\end{tabular}

a. Predictors: (Constant), waktu, Preservatives

b. Dependent Variable: bakterii

2. Uji Univariat didapatkan hasil hipotesis sebagai berikut.

Uji diantara efek subjek jumlah SPC bakteri dan preservatives menunjukkan nilai signifikansi kurang dari 0,05 yaitu 0,000 yang menunjukkan

a. H1 diterima yang artinya terdapat perbedaan efek ketiga preservatives terhadap jumlah SPC bakteri. b. H1 diterima yang artinya terdapat perbedaan jumlah SPC bakteri karena waktu perendaman berbeda yaitu 1, 3 dan 6 hari dengan nilai $p$ $<0,05$

c. H1 diterima yang artinya terdapat interaksi preservatives* ${ }^{*}$ waktu terhadap jumlah $S P C$ bakteri dilihat dengan nilai $p<0,05$ yaitu 0,043

Tabel 3 . Hasil uji waktu pemaparan preservatives dengan jumlah SPC bakteri Tests of Between-Subjects Effects

Dependent Variable:bakterii

\begin{tabular}{lrrrrr}
\hline Source & $\begin{array}{c}\text { Type III Sum } \\
\text { of Squares }\end{array}$ & Df & Mean Square & \multicolumn{1}{c}{ F } & \multicolumn{1}{l}{ Sig. } \\
\hline Corrected Model & $1.785 \mathrm{E} 16^{\mathrm{a}}$ & 26 & $6.865 \mathrm{E} 14$ & 4.808 & .000 \\
Intercept & $9.938 \mathrm{E} 16$ & 1 & $9.938 \mathrm{E} 16$ & 695.934 & .000 \\
Preservatives & $1.075 \mathrm{E} 16$ & 8 & $1.344 \mathrm{E} 15$ & 9.410 & .000 \\
Waktu & $2.959 \mathrm{E} 15$ & 2 & $1.480 \mathrm{E} 15$ & 10.361 & .000 \\
Preservatives * & $4.141 \mathrm{E} 15$ & 16 & $2.588 \mathrm{E} 14$ & 1.812 & .043 \\
waktu & $1.157 \mathrm{E} 16$ & 81 & $1.428 \mathrm{E} 14$ & & \\
Error & $1.288 \mathrm{E} 17$ & 108 & & & \\
Total & $2.942 \mathrm{E} 16$ & 107 & & & \\
Corrected Total & & & & &
\end{tabular}

a. R Squared $=.607$ (Adjusted R Squared $=.481$ )

Untuk menentukan konsentrasi diantara jenis preservatives yang bermakna signifikan dilakukan uji Scheffe. Nilai $p<0,05$ menunjukkan perbedaan yang signifikan diantara konsetrasi jenis preservatives.

dengan nilai $p<0,05$ menunjukkan perbedaan bermakna diantara konsentrasi preservatives. Jumlah SPC bakteri pada tahu yang sebelum direndam adalah 2,1.10 TBUD>300 (TBUD>300 menunjukkan ada bakteri yang dihitung lebih dari 300 koloni pada tahap pengenceran) per $\mathrm{ml}$ sampel, tetapi yang digunakan adalah penghitungan bakteri hanya 30-300 koloni sehingga didapatkan angka jumlah bakteri 2,1.10 ${ }^{7}$. Bakteri yang diisolasi dari tahu berasal dari bahan baku yang tercemar, lingkungan tempat pembuatan dan peralatan yang dipergunakan. Nilai SPC tahu yang dibuat, belum bisa dibandingkan dengan batas 
ambang yang ditetapkan oleh BPOM RI, karena jumlah ambang batas SPC bakteri untuk tahu segar, peneliti belum mendapatkan sumbernya. Penelitian Mustafa (2006) mendapatkan bahwa jumlah total mikroba pada awal penyimpanan pada tahu yang digunakan berjumlah $4.75 \times 10^{6}$. Sedangkan penelitian ini menemukan jumlah SPC bakteri pada tahu yang sebelum direndam adalah $2,1.10^{7}$ per $\mathrm{ml}$ sampel, memang mendekati seperti apa yang ditemukan oleh Mustofa. Jumlah koloni bakteri yang dihitung antara 30-300 koloni.

Bakteri ini berasal selama proses pembuatan tahu. Protein dari kedelai juga membantu pertumbuhan bakteri. Pemilihan preservatives didasarkan pada ditemukan bahan kimia berbahaya yang dipergunakan untuk pengawetan tahu.

Komposisi tahu yang banyak mengandung protein dan air menyebabkan tahu merupakan media yang cocok untuk tumbuhnya mikroba sehingga tahu menjadi cepat mengalami kerusakan (Sarwono \& Saragih 2003).

Hasil Gain Score mendapatkan tahu yang direndam dengan preservatives alami sereh hari I pada konsentrasi $20 \%, 40 \%$ dan $60 \%$ adalah berturut turut $-3,0.10^{6}, 2,0.10^{6}$, $4,0.10^{6}$. Hanya tahu yang direndam dengan preservative alami sereh konsentrasi $20 \%$ yang menunjukkan peningkatan jumlah bakteri ditandai dengan tanda minus (-), artinya preservative sereh konsentrasi $20 \%$ tidak menghambat pertumbuhan bakteri yang hidup pada tahu. Pada hari ke-3 dan ke-6, tahu yang direndam dengan konsentrasi $40 \%$ dan $60 \%$ yang menghambat pertumbuhan bakteri. Uji Scheffe menunjukkan bahwa terjadi perbedaan yang signifikan preservatives sereh konsentrasi $20 \%$ dengan 60\% terhadap jumlah SPC bakteri. Sibel (2003) menyatakan bahwa semua rempah mengandung Eugenol dan Methyl eugenol. Penelitian yang dilakukan oleh Suprianto (2008), membukti-kan bahwa ekstrak etanol dan ekstrak air batang dan daun sereh wangi memiliki potensi dalam menghambat pertumbuhan bakteri $S$. mutans. Aktivitas ekstrak etanol batang dan daun sereh wangi lebih besar dari ekstrak air dalam menghambat pertumbuhan bakteri $S$. mutans. Selain senyawa sitronellal, geraniol dan sitronellol, senyawa sitral merupakan kelompok senyawa terpen yang terdiri dari campuran isomer bioaktif nerol dan geraniol yang merupakan salah satu komponen penyusun dalam minyak atsiri sereh. Menurut Burdock (2002) komponen senyawa utama minyak sereh wangi ini terdiri dari sitronelal, sitronellol, dan geraniol. Luangnarumitchai et al. (2007) memaparkan bahwa kandungan sitronelal, geraniol, dan sitronelol dalam minyak sereh wangi juga mampu menghambat aktivitas bakteri. Putriningtyas (2014) dalam studinya melaporkan bahwa minyak atsiri daun sereh wangi asal Tawangmangu mampu menghasilkan zona hambat terhadap $S$. aureus dan E. coli. Hasil penelitian menunjukkan bahwa aktivitas antibakteri minyak atsiri daun sereh wangi lebih besar terhadap bakteri $S$. aureus. Penelitian lain yang dilakukan oleh Brugnera et al., 2011 (Bota, dkk., 2015), minyak atsiri daun sereh wangi asal Brazil yang memiliki komponen kimia sitronellal $(34,6 \%)$, geraniol $(23,17 \%)$, dan sitronellol $(12,09 \%)$ juga mampu menghambat aktivitas bakteri $S$. aureus serta mampu menghambat aktivitas bakteri Gram negatif yaitu $E$. colidan $P$. aeruginosa.

Kunyit menimbulkan aroma yang khas. Perlakuan yang diberikan pada konsentrasi kunyit yang terlalu tinggi akan menurunkan tingkat kesukaan konsumen terhadap produk tersebut. Proses pengawetan suatu bahan pangan yang diberikan pengawet rempah-rempah, terutama kunyit akan mempengaruhi kerja zat aktif antimikroba yang terdapat dalam rempah-rempah tersebut dalam kondisi konsentrasi yang tidak terlalu rendah. Pada awal penyimpanan, total mikroba pada tahu yang digunakan berjumlah $4.75 \times 10^{6}$ Pada hari ke dua, semua tahu yang mengalami perlakuan mulai mengalami tanda-tanda kerusakan, seperti adanya lendir, aroma sedikit asam, kekompakan berkurang, dan larutan perendam yang sangat keruh serta terdapat residu (semacam lendir) pada larutan perendamnya. Hal ini kemungkinan disebabkan taraf konsentrasi yang digunakan belum cukup efektif untuk menghambat pertumbuhan mikroba pada tahu yang berbeda dengan bahan makanan lainnya. Konsentrasi yang digunakan untuk kedua bentuk bahan pengawet alami 
tersebut adalah untuk kunyit $0.2,0.4,0.6$, $0.8,1 \% \quad(w / v)$ (Mustofa, 2006). Dua komponen utama yang menentukan mutu kunyit adalah kandungan pigmen kurkumin (C12H2006) dan kandungan minyak volatilnya. Kandungan pigmen kunyit (dinyatakan dengan kurkumin) dan minyak volatil dari berbagai jenis kunyit yang diperdagangkan berkisar antara 0.5-6.0\% dan 1.3-6.0\% (Pursgelove et al. 1981). Minyak ini mengandung alkohol, turmerol, dan curcumin sedangkan bagian utama dari minyak ini adalah turmeron dan aldehidroturmeron. Komponen organik lainnya adalah $d$ - $\alpha$-phelandren, dsabinen, zingiberen, cineol, dan borneol. Kunyit bersifat bakterisidal terhadap bakteri gram positif, yaitu Lactobacillus fermentum, $L$. Bulgaricus, Bacillus cereus, B. Subtilis, dan $B$. megaterium dan diduga kunyit mengandung lebih dari satu senyawa yang bersifat bakterisidal, dan salah satu senyawa tersebut disebabkan oleh senyawa kurkumin yang merupakan senyawa golongan fenol yang terdiri dari dua cincin fenol simetris dan dihubungkan dengan satu rantai heptadiena (Suwanto 1983). Senyawa fenol menghambat pertumbuhan mikroba dengan cara merusak membran sel yang akan menyebabkan denaturasi protein sel dan mengurangi tekanan permukaan sel (Mustafa, 2006). Sedangkan Sibel (2003) menyatakan bahwa kunir mengandung Cuminaldehyde. Hasil Gain Score pada penelitian ini mendapatkan tahu yang direndam dengan preservatives alami kunyit pada hari ke-1 dan ke-6 dengan konsentrasi $20 \%, 40 \%$ dan $60 \%$ menunjukkan peningkatan jumlah bakteri ditandai dengan tanda minus (-), artinya preservative kunyit semua konsentrasi tidak menghambat pertumbuhan bakteri yang hidup pada tahu. Pada hari ke-3, hanya tahu yang direndam dengan konsentrasi $60 \%$ yang menghambat pertumbuhan bakteri. Uji Scheffe menunjukkan bahwa terjadi perbedaan yang signifikan preservatives kunyit konsentrasi 20\% dengan $60 \%$ terhadap jumlah SPC bakteri.

Manfaat rimpang lengkuas telah dipelajari oleh para ilmuwan sejak dulu. Rimpang lengkuas memiliki berbagai khasiat diantaranya sebagai antijamur dan antibakteri. Penelitian Yuharmen dkk. (2002) menunjukkan adanya aktifitas penghambatan pertumbuhan mikrobia oleh minyak atsiri dan fraksi methanol rimpang lengkuas pada beberapa spesies bakteri dan jamur. Penelitian Sundari dan Winarno (2000) menunjukkan bahwa infus ekstrak etanol rimpang lengkuas yang berisi minyak atsiri dapat menghambat pertumbuhan beberapa spesies jamur patogen, yaitu: Tricophyton, Mycrosporum gypseum, dan Epidermo floccasum. Ekstrak rimpang lengkuas (Alpinia galanga) memiliki aktivitas antijamur terhadap jamur filamentus, meskipun tidak kuat ( Handajani \& Purwoko, 2008). Secara tradisional rimpang lengkuas digunakan untuk mengobati penyakit panu, kadas, bronkitis, dan reumatik. Senyawa kimia utama lengkuas adalah minyak atsiri yang tersusun atas eugenol, seskuiterpen, pinen, metil-sinamat, kaemferida, galangan, dan galangol. Rimpang lengkuas yang digunakan dalam penelitian ini adalah rimpang lengkuas merah. Minyak atsiri lengkuas merah mengandung 12 senyawa dan didominasi oleh sineol, karanol, dan farnesen (Jamal dkk., 1996). Mekanisme penghambatan pertumbuhan ekstrak rimpang lengkuas kemungkinan melalui perusakan permeabilitas membran sel (Haraguchi dkk., 1996). Penerapan ekstrak rimpang lengkuas harus hati-hati, karena memiliki efek sitotoksisitas dan mampu merusak DNA pada enam sel manusia (human cell line), yaitu sel normal, sel p53inaktif, fibroblast, sel epitelium normal, sel tumor payudara dan sel adenokarsinoma paru-paru (Muangnoi dkk., 2007). Menurut (Chudiwal et al., 2010) rhizome lengkuas (Alpinia galanga) diisolasi bahan kimia antara lain : 1, S'-1'-acetoxychavicol acetate, 1. S'-1-acetoxyeugenol acetate, 1, S'-1,hydroxychavicol acetate, trans-p hydroxycinnamaldehyde, trans-p-coumaryl alcohol, trans-p hydroxycinnamyl acetate dan trans-p coumaryl diacetate. Hasil Gain Score pada penelitian ini mendapatkan tahu yang direndam dengan preservatives alami lengkuas pada hari ke-1 hanya konsentrasi $40 \%$ yang menunjukkan penghambatan jumlah bakteri. Pada hari ke-3 dan ke-6, tidak ada konsentrasi preservatives lengkuas menghambat pertumbuhan bakteri. Uji Scheffe menunjukkan bahwa terjadi perbedaan yang signifikan 
preservatives lengkuas konsentrasi $20 \%$ dengan $60 \%$ terhadap jumlah SPC bakteri.

Dari uji univariat didapatkan perbedaan yang signifikan terhadap pertumbuhan SPC bakteri karena pemberian preservatives. Uji lanjut Scheffe menunjukkan bahwa jumlah SPC bakteri yang direndam dengan preservatives sereh konsentrasi $40 \%$ berbeda bermakna dengan preservatives kunyit konsentrasi $20 \%$ dan lengkuas $20 \%$. Jumlah SPC bakteri yang direndam dengan preservatives sereh konsentrasi $60 \%$ berbeda bermakna dengan preservatives kunyit konsentrasi $20 \%$, lengkuas $20 \%$ dan lengkuas $40 \%$. Jumlah SPC bakteri yang direndam dengan preservatives kunyit $20 \%$ berbeda bermakna dengan preservatives sereh $40 \%$ dan sereh $60 \%$. Jumlah SPC bakteri yang direndam dengan preservative lengkuas $200 \%$ berbeda bermakna dengan preservatives sereh $40 \%$ dan sereh $60 \%$. Jumlah SPC bakteri yang direndam dengan preservatives lengkuas $40 \%$ berbeda bermakna dengan preservatives sereh $60 \%$ dengan $p<0,05$.

2. Zona hambatan preservatives alami pada media NA terhadap bakteri hasil isolasi dari makanan tahu dan bakteri uji Staphylococcus aureus

Hasil uji zona hambatan preservatives terhadap bakteri hasil isolasi dari makanan tahu dan bakteri uji Staphylococcus aureus tertera pada tabel di bawah ini.

Tabel 4. Hasil Pengamatan Terhadap Zona Hambatan koloni bakteri

\begin{tabular}{|c|c|c|c|c|c|c|c|}
\hline \multirow[t]{2}{*}{$\begin{array}{l}\text { Hari } \\
\text { perendaman }\end{array}$} & \multicolumn{4}{|c|}{$\begin{array}{l}\text { Rata-rata Zona hambatanBakteri yang } \\
\text { hidup pada makanan tahu oleh } \\
\text { preservatives alami (cm) }\end{array}$} & \multicolumn{3}{|c|}{$\begin{array}{l}\text { Zona hambatan pada bakteri } S \text {. } \\
\text { aureus oleh preservatives alami } \\
(\mathrm{cm})\end{array}$} \\
\hline & & Kunyit & Sereh & Lengkuas & Sereh & Lengkuas & Kunyit \\
\hline \multicolumn{8}{|l|}{$\mathrm{H} 1$} \\
\hline & $0 \%$ & 0 & 0 & 0 & 0 & 0 & 0 \\
\hline & $20 \%$ & 0 & 0 & 0 & 0 & 0 & 0 \\
\hline & $40 \%$ & 0,525 & 0,425 & 0,55 & 0,7 & 0,8 & 1 \\
\hline & $60 \%$ & 0,9 & 0,9 & 0,825 & 1 & 1 & 1,5 \\
\hline \multicolumn{8}{|l|}{$\mathrm{H} 3$} \\
\hline & $0 \%$ & 0 & 0 & 0 & 0 & 0 & 0 \\
\hline & $20 \%$ & 0 & 0 & 0 & 0 & 0 & 0 \\
\hline & $40 \%$ & 0 & 0 & 0 & 0 & 0,5 & 0,8 \\
\hline & $60 \%$ & 0,475 & 0,5 & 0,575 & 1 & 0,8 & 1 \\
\hline
\end{tabular}

Analisis Zona Hambatan Preservatives Alami Terhadap Pertumbuhan Bakteri yang Tumbuh pada Makanan Tahu

Sebelum dilakukan uji univariat dilakukan uji prasyarat yaitu :

1. uji non parametrik Kolmogorov Smirnov (KS) didapatkan bahwa data berdistribusi normal

2. Uji univariat didapatkan hasil sebagai berikut.

1. Uji diantara efek subjek zona hambatan karena ketiga preservatives menunjukkan nilai $\mathrm{p}<$ 0,05 yaitu 0,00 yang menunjukkan $\mathrm{H} 1$ diterima yang artinya terdapat perbedaan zona hambatan karena perendaman tahu pada ketiga preservatives terhadap pertumbuhan bakteri.

2. Uji terhadap waktu perendaman terhadap zona hambatan bakteri menunjukkan nilai signifikan dengan nilai $p<0.05$ yaitu 0,00 yang menunjukkan bahwa waktu perendaman berpengaruh signifikan terhadap zona hambatan (H1 diterima).

3. H1 diterima terhadap interaksi yaitu terdapat interaksi preservatives*waktu terhadap zona hambatan dengan nilai $p<0.00$ 
Tabel 5. Hasil uji normalitas sebaran data

One-Sample Kolmogorov-Smirnov Test

\begin{tabular}{|c|c|c|}
\hline & & Zona \\
\hline $\mathrm{N}$ & & 72 \\
\hline \multirow[t]{2}{*}{ Normal Parameters ${ }^{a}$} & Mean & .3153 \\
\hline & Std. Deviation & .38112 \\
\hline Most Extreme & Absolute & .338 \\
\hline \multirow[t]{2}{*}{ Differences } & Positive & .338 \\
\hline & Negative & -.204 \\
\hline \multicolumn{2}{|c|}{ Kolmogorov-Smirnov Z } & 2.865 \\
\hline \multicolumn{2}{|l|}{ Asymp. Siq. (2-tailed) } & .000 \\
\hline
\end{tabular}

a. Test distribution is Normal.

Tabel 6. Hasil uji univariat zona hambatan preservatives terhadap pertumbuhan bakteri

Tests of Between-Subjects Effects

Dependent Variable:zona

\begin{tabular}{|c|c|c|c|c|c|c|}
\hline Source & $\begin{array}{l}\text { Type III Sum } \\
\text { of Squares }\end{array}$ & Df & Mean Square & $F$ & Sig. & $\begin{array}{l}\text { Partial Eta } \\
\text { Squared }\end{array}$ \\
\hline Corrected Model & $8.306^{a}$ & 17 & .489 & 13.142 & .000 & .805 \\
\hline Intercept & 7.157 & 1 & 7.157 & 192.512 & .000 & .781 \\
\hline Preservatives & 5.982 & 8 & .748 & 20.114 & .000 & .749 \\
\hline Waktu & 1.473 & 1 & 1.473 & 39.635 & .000 & .423 \\
\hline $\begin{array}{l}\text { Preservatives * } \\
\text { waktu }\end{array}$ & .850 & 8 & .106 & 2.859 & .010 & .298 \\
\hline Error & 2.008 & 54 & .037 & & & \\
\hline Total & 17.470 & 72 & & & & \\
\hline Corrected Total & 10.313 & 71 & & & & \\
\hline
\end{tabular}

a. $\mathrm{R}$ Squared $=.805$ (Adjusted R Squared $=.744$ )

Dan gambaran (profil) zona hambatan

dengan preservatives alami digambarkan pertumbuhan bakteri yang direndam seperti gambar 1 di bawah ini.

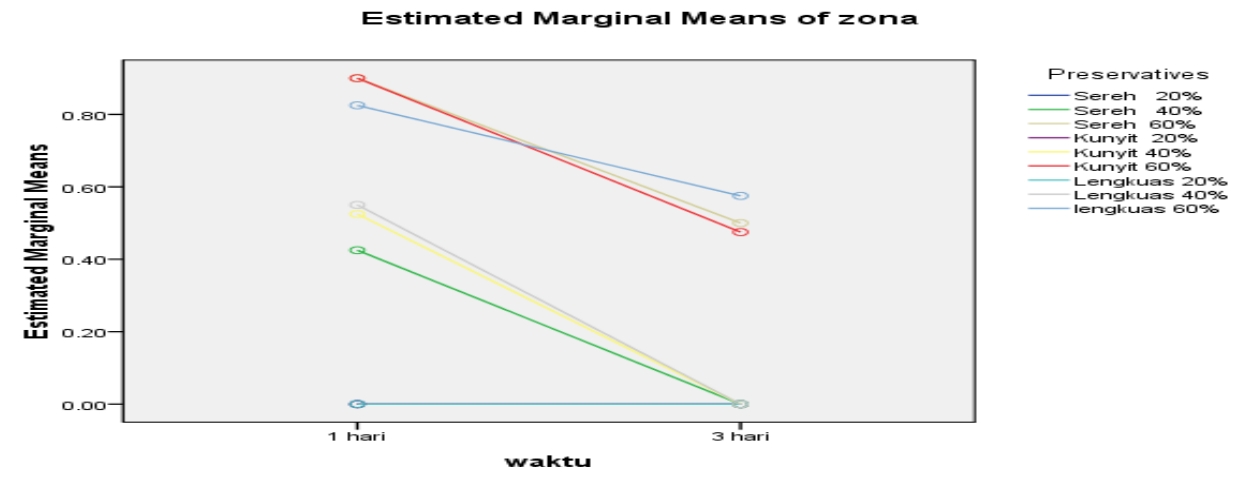

Gambar 1. Profil zona hambaatn konsentrasi preservatives terhadap pertumbuhan bakteri

Uji lanjut Scheffe diantara ketiga preservatives terhadap zona hambatan pertumbuhan bakteri dengan nilai $p<0,05$ menunjukkan perbedaan bermakna diantara 
konsentrasi preservat. Analisis univariat pada zona hambatan preservatives alami didapatkan bahwa terdapat perbedaan zona hambatan pertumbuhan bakteri oleh ketiga preservatives alami dan perbedaan waktu perendaman terhadap zona hambatan pertumbuhan bakteri akibat ketiga jenis preservatives. Analisis lanjut Scheffe didapatkan hasil : zona hambatan oleh sereh konsentrasi $20 \%$ dan $40 \%$ berbeda bermakna dibandingkan dengan zona hambatan oleh kunyit $60 \%$ dan lengkuas $60 \%$ terhadap pertumbuhan bakteri. Zona hambatan oleh sereh konsentrasi $60 \%$ berbeda bermakna dibandingkan dengan zona hambatan oleh ketiga preservatives konsentrasi $20 \%$ dan $40 \%$ terhadap pertumbuhan bakteri. Zona hambatan oleh kunyit konsentrasi $20 \%$ berbeda bermakna dibandingkan dengan zona hambatan oleh ketiga preservatives konsentrasi $60 \%$ terhadap pertumbuhan bakteri. Zona hambatan oleh kunyit konsentrasi 40\% berbeda bermakna dibandingkan dengan zona hambatan oleh ketiga preservatives konsentrasi $60 \%$ terhadap pertumbuhan bakteri. Zona hambatan oleh kunyit konsentrasi $60 \%$ berbeda bermakna dibandingkan dengan zona hambatan oleh ketiga preservatives konsentrasi $20 \%$ dan $40 \%$ terhadap pertumbuhan bakteri. Zona hambatan oleh lengkuas konsentrasi $20 \%$ dan $40 \%$ berbeda bermakna dibandingkan ketiga preservatives konsentrasi $60 \%$ terhadap pertumbuhan bakteri. Zona hambatan oleh lengkuas konsentrasi $60 \%$ berbeda bermakna dibandingkan dengan zona hambatan oleh ketiga preservatives konsentrasi $20 \%$ dan $40 \%$ terhadap pertumbuhan bakteri. Adanya zona hambatan disebabkan bahan aktif yang terdapat pada ketiga preservatives.

\section{Uji koefisien phenol dari preservatives alami}

Bakteri uji yang digunakan adalah bakteri Staphylococcus aureus yang diinkubasi pada inkubator $1 \times 24$ jam pada suhu $37^{\circ} \mathrm{C}$. Uji ke-3 ekstrak germisida yaitu sereh, kunyit dan lengkuas semuanya menunjukkan sama atau kurang efektif dibandingkan dengan fenol karena nilai koefisien phenol dari bahan kimia uji menunjukkan angka kurang dari 1 dari formula :

Koefisien phenol dari bahan kimia uji $=$

uji larutan germisida yang menunjukkan tidak tumbuh pada paparan 10 menit, tetapi tumbuh pada paparan 5 menit uji larutan phenol yang menunjukkan tidak tumbuh pada paparan 10 menit, tetapi tumbuh pada paparan 5 menit

\section{PENUTUP}

\section{Simpulan}

Simpulan dari penelitian ini adalah : (1) Tahu yang berhasil dibuat masih belum memenuhi standar penilaian SNI 01-31421992 yaitu pada bagian rasa, yaitu sebanyak $50 \%$ panelis yang menyatakan rasa tahu sedikit asam (2) Uji organoleptik makanan tahu pada hari pertama perendaman dengan preservatives alami, sebanyak $100 \%$ panelis menyatakan tahu yang direndam dengan ke3 preservative alami beraroma dan rasa harum preservatives alami (sereh, kunyit dan lengkuas). Karakteristik warna tahu, $100 \%$ panelis menyatakan putih bersih atau kekuningan bersih dan $100 \%$ panelis menyatakan penampakkan normal tidak berlendir dan berjamur (3) Terjadi penurunan kualitas tahu dari uji organoleptik, analisis secara statistik dengan gain score dan univariat untuk SPC bakteri dan zona hambatan pertumbuhan bakteri (4) Uji koefisien phenol menunjukkan ke- 3 preservatives alami yang diektrak dengan hidrodestilasi sama atau kurang efektif dibandingkan phenol.

\section{Saran}

Perlu dilakukan uji lanjutan pada makanan tahu yang dipreservasi dengan preservatives alami terhadap kerusakan hati dengan menentukan kadar SGOT (Serum Glutamic Oxaloacetate Transaminase) dan SGPT (Serum Glutamic Piruvic Transaminase) pada hewan coba, mengingat bahan preservatives alami mengandung alkohol.

\section{Ucapan Terimakasih}

Ucapan terimakasih disampaikan kepada : (1) Pemerintah RI, Kemenristek Dikti melalui Dana DIPA Undiksha, (2) Para panelis (3) Semua pihak yang membantu dalam penelitian ini. 


\section{DAFTAR PUSTAKA}

Afrianto, E. 2008. Pengawasan Mutu Produk Bahan Pangan . Direktorat Pembinaan Sekolah Menengah Kejuruan Dirjen Manajemen Pendas dan Depdiknas.

Anonim. 2003. Membuat Susu Kedele dan Tahu. Direktorat Pendidikan Menengah Kejuruan. Dirjen Pendidikan dasar dan Menengah. Depdiknas

Aprilianti, A., Ma'ruf, A.., Fajarini, Z.N., Purwanti, D. 2007. Studi Kasus Penggunaan Formalin pada Tahu Takwa di Kotamadya Kediri. PKM UM.

Badan Pengawas Obat dan Makanan. 2013. Peraturan Kepala Badan Pengawas Obat dan Makanan R.I Nomor 36 TAHUN 2013 Tentang Batasan Maksimum Penggunaan Bahan Tambahan Pangan Pengawet. Jakarta : BPOM

Bota,W., Mastosupono, M., Rondonuwu, F.S. 2015. Potensi Senyawa Minyak Sereh Wangi (Citronella Oil) dari Tumbuhan Cymbopogon nardus Sebagai Agen Antibakteri. Semnas Saintek. Fak Teknik Muhammadiyah Jakarta.

Cahyadi, W. 2008. Analisis dan Aspek Kesehatan Bahan Tambahan Pangan: Jakarta . Bumi Aksara

Cappuccino, J.G., Sherman, N. 1987. Microbiology: A Laboratory Manual. California, Massachusetts, Ontario, Wokingham, Amsterdam, Sydney, Singapore, Tokyo, Madrid, Bogota, Santiago, San Juan : The Benjamin/Cummings Pub. Company, Inc

Chudiwal, A.K., Jain, D.P., Somani, R.S. 2010. Alpinia galangal Wild. An Overview on Phyto-Pharmacological Properties. IndianJournal of NatProdand resource. Vol 1 (2) : 143149

Cui Z. 2003. Determination of chemical constituents of the essential oil from Alpinia galanga (L.) by GCMS. Lixueban.

Depkes, 1996. Daftar Komposisi Bahan Makanan. Direktorat Gizi: Jakarta. Departemen Kesehatan RI.

Deputi Bidang Pengawasan Keamanan Pangan dan Bahan Berbahaya BPOM
RI. 2012. Pedoman Kriteria Cemaran Pada Pangan Siap Saji dan Pangan Industri Rumah Tangga. Direktorat Standarisasi Produk Pangan BPOM RI

Duke, J. 2008. Andropogon ciratus species Activity Information, Dr. Duke's Phytochemical dan Ethnobotanical Database. (Online) (http://sun.arggrin.gov-808, diakses pada tanggal 12 Desember 2011)

Fardiaz,S . 1988. Mikrobiologi Pengolahan Pangan Lanjut. IPB Press. Bogor.

Fardiaz, S. 1993. Analisis Mikrobiologi Pangan. Bogor : PAU Pangan dan Gizi.IPB : p.42

Florensia, S., Dewi, P., Utami, N.R. 2012. Pengaruh Ekstrak Lengkuas pada Perendaman lkan Bandeng terhadap Jumlah Bakteri : Semarang. Unnes J. of Life Science

Handajani., N.S. dan Purwoko, Tj. 2008. Aktivitas Ekstrak Rimpang Lengkuas (Alpinia galangal) terhadap Pertumbuhan Jamur Aspergillus spp. Penghasil Aflatoksin dan Fusarium monoliforme . Biodiversitas. 9 (3) : 161164

Haraguchi, H., Y. Kuwata, K. Inada, K. Shingu, K. Miyahara, M. Nagao, and A. Yagi. 1996. Antifungal activity from Alpinia galanga and the competition for incorporation of unsaturated fatty acids in cell growth. Planta Medica 62:308313.

Harmoni, D. 2006. Seluk Beluk Formalin. www.hd.co.id

Irawan, A.C., Widodo, E., Djunaidi, I.H. 2013. Pengaruh Pemberian Sari Kunyit (Tumeric) Terhadap Jumlah Mikroflora Usus Itik Pedaging. Malang : Univ. Brawijaya

Jirawan O, Tomoko S. 2006. Antimicrobial properties and action of galangal (Alpinia galanga Linn.) on Staphylococcus aureus. LWT-Food and Science Technology : 39: 1214-1220

Jamal, Y., Murningsih, T dan P.N. Evita. 1996. Identifikasi minyak atsiri dan uji kuantitatif dari lengkuas merah (Alpinia galanga L.). Bogor: Puslitbang Biologi, LIPI.

Jivai, J., Yetti, N. 2008. Pengaruh Pemberian Tahu Berformalin Terhadap Gangguan Fungsi Hati dan 
Terbentuknya Radikal Bebas dalam Tubuh Tikus Putih. J.Saintek. Farmasi. $13(1)$

Joe. 2004. Senyawa Kimia yang Terdapat Pada Rempah - Rempah. Universitas Indonesia press. Jakarta.

Junqueira, L.C.J. and R.O. Kelley. 1992. Histologi Dasar. Edisi III. Alih bahasa J. Tembayong : Jakarta. Buku Kedokteran Karyasa, I.W. 2000. Bangga Makan Tahu Tempe. Forum Diskusi Indonesia, Berlin. Jakarta

Kastyanto. 1994. Membuat Tahu. Penebar Swadaya, Jakarta.

Menteri Kesehatan (Menkes) Nomor 1168/Menkes/PER/X/1999 Tentang Bahan Makanan Tambahan.

Midayanto, D.N dan Yuwono, S.S. 2014. Penentuan Atribut Mutu Tekstur Tahu untuk Direkomendasikan Sebagai Syarat Tambahan Dalam Standar Nasional Indonesia. J.Pangan\&Agroind. 2(4) : 259-267

Muangnoi, P., M. Lu, J. Lee, A. Thepouyporn, R. Mirzayans, X.C. Le, M. Weinfeld, and S. Changbumrung. 2007. Cytotoxicity, apoptosis and DNA damage induced by Alpinia galanga rhizome extract. Planta Medica 73:748754

Mustafa, R.M. 2006. Study Efektivitas Bahan Pengawet Alami Dalam Pengawetan Tahu. Prodi Gizi Masyarakat : Bogor. IPB

Norma, Latif, U.T.A., Usma, S. 2014. Efek Hepatoksisitas Ekstrak Etanol herba Kompri (Symphytum Officinale L) Terhadap Hewan Uji Kelinci (Oryctolagus cuniculus) dengan Parameter SGOT dan SGPT. Genesis. J.IImiah Biol

Nuryasin, A. 2006. Bahaya Formalin. http://ikap=kdk.com/arpan/content/view/ III

Octaviani (2007) Octaviani, R. 2007. Profil Kromatogram dan Aktivitas Antibakteri Ekstral Etanol Rimpang Lempuyang Gajah ( Zingiber zerumbet) terhadap Bakteri Escherichia coli in Vitro. http://eprints.undip.ac.id/22663/1/Rima. pdf. Diakses tanggal 20 Nopember 2012.

Peraturan Kepala Badan Pengawas Obat dan Makanan Republik Indonesia
Nomor 16 Tahun 2016 Tentang Kriteria Mikrobiologi dalam Pangan Olahan. 2016. Jakarta : BPOM

Pratiwi, I., Kurniaty, N., Arumsari, A. 2015. Analsisis Kadar Kuning Metanil dalam Tahu Kuning dengan Metode Kromatographi Cair Kinerja Tinggi. Proseding Penelitian SpeSIA

Purba, R., Suseno, S.H., Izaki, A.F., Muttaqin, S. 2014. Application of Liquid Smoke and Chitosan as Natural Preservatives for Tofu and Meatballs. Int.J. of Applied Science Tech. 4 (2)

Rahmawati, F. Tanpa tahun. Pengawetan Makanan dan Permasalahannya : Yogyakarta. Jurusan Pendidikan Teknik Boga dan Busana. FT. UNY

Sampurno. 2006. Keterangan Pers Kepala BPOM RI. No. Kh. 00.01.1241.029 Tentang Hasil Tindak Lanjut Pengawasan Terhadap Penyalahgunaan Formalin sebagai Pengawet Tahu Dan Mi Basah. Jakarta

Sarwono,S dan Saragih Y.P.2003. Membuat Aneka Tahu. Penebar Swadaya, Jakarta.

Shurtleff, W. dan Aoyagi, A., 2001. The Book of Tofu. Ten Speed Press, California.

Sibel, R. 2003. Natural Antimikrobias for the Minimal Processing of Foods. Cambridge, GBR: Woodhead Publishing, Limited. Hal: 177.

Smith FM, West NH, Jones DR. 2000. The Cardiovascular System. In: Whittow GC, editor.Sturkie's Avian Phisiology. Fifth edition. USA: AcademicPress.

Sundari, D. dan M.W. Winarno. 2000. Informasi tumbuhan obat sebagai anti jamur. Jakarta: Puslitbang-Balitbangkes Depkes RI.

Tajbakhsh, S., K. Mohammadi, I. Deilami, K. Zandi, M. Fouladvand, E. Ramedani and G.Asayesh, 2008. Antibacterial Activity of Indium Curcumin and Indium Diacetylcurcumin. J Biotechnol 7: 38323835.

Winarno, F. G. dan T. S. Rahayu. 1994. Bahan Tambahan untuk Makanan dan Kontaminan. : Jakarta. Pustaka Sinar Harapan. .

Yalcinkaya, L., T. M. Gonggor, Basalan and E. Erdem. 2008. Mannan oligosaccharides (MOS) from Saccharomyces cerevisiae in broilers: 
Effects on performance and blood biochemistry. Turk. J. Vet. Anim. Sci. Vol : 32 (1) : 43-48.

Yuharmen, Y., Y. Eryanti, dan Nurbalatif. 2002. Uji Aktivitas Antimikrobia Minyak
Atsiri dan Ekstrak Metanol Lengkuas (Alpinia galanga). J. Nature Indonesia, 4 (2): 178-183. 